\title{
Effects of stress produced by adrenocorticotropin (ACTH) on lipid peroxidation and some antioxidants in vitamin $\mathrm{C}$ treated and nontreated chickens
}

\author{
F. Belge ${ }^{1 \#}$, A. Çınar ${ }^{1}$ and M. Selçuk ${ }^{2}$ \\ ${ }^{1}$ University of Yuzuncu Yil, Faculty of Veterinary Medicine, Department of Physiology, Van, Turkey \\ ${ }^{2}$ University of Yuzuncu Yil, Education Faculty, Department of Physcial Education and Sport, Van, Turkey
}

\begin{abstract}
The aim of this study was to examine the effects of vitamin $\mathrm{C}$ on malonaldehyde (MDA) and glutathione (GSH) concentrations, and superoxide dismutase (SOD) and glutathione peroxidase (GSH-Px) activity in chickens stressed by adrenocorticotropin (ACTH). Sixty Leghorn chickens (20 weeks old) were randomly allotted to a control and a vitamin $\mathrm{C}$ treated group. An isotonic sodium chloride solution was administrated intramuscularly for a period of five days to the control group at a dose of $2.5 \mathrm{~mL}$ per chicken per day, and the treatment group received a vitamin $\mathrm{C}$ solution (containing $250 \mathrm{mg}$ vitamin $\mathrm{C} / 2.5 \mathrm{~mL}$ ) intramuscularly for five days. On the fifth day of the experiment the chickens in both groups received 50 IU ACTH intramuscularly. Three hours after ACTH application blood samples were collected to determine the concentrations of MDA and GSH, and activities of SOD and GSH-Px in the blood. The concentration of MDA in the control group increased compared to that in the vitamin $\mathrm{C}$ treated group. After the ACTH application the activity of SOD increased in both groups, thought significantly so in the vitamin $\mathrm{C}$ treated group. The GSH-Px activity did not differ significantly between the treatments after ACTH application. It was concluded that intramuscularly administrated vitamin $\mathrm{C}$ facilitated an adaptation against stress and decreased negative effects of stress in chickens.
\end{abstract}

Keywords: ACTH, glutathione (GSH), glutathione peroxidase (GSH-Px), malonaldehyde (MDA), superoxide dismutase (SOD), vitamin C

${ }^{\#}$ Corresponding author. E-mail: alicinar25@mynet.com

\section{Introduction}

Physiological stress is not a disease, but too much stress is unhealthy and counterproductive and can affect many systems and causes a decrease in animal productivity. Some researchers (Siegel, 1971; Gray et al., 1989; Emre et al., 1994; Puvaldopirod \& Thaxton, 2000) have reported that stress in birds can be produced experimentally by the injection of adrenocorticotropin (ACTH). Stress is believed to cause many diseases in living beings due to its negative effects in the body. Some of the negative effects are increased biological oxidation, depression of the immune system against infections, reduction of reproduction rate and growth in the organism, metabolic malfunction causing feeding disorders, etc. (Gray et al., 1989; Puvadolpirod \& Thaxton, 2000; Whittow, 2000). This situation causes the formation and increase of free radicals in the body and associated negative effects. While radicals affect all the biomolecules in the organism their principal targets are membrane lipids, other lipids, proteins and DNA (Jain et al., 1989; Husveth et al., 2000; Puthpongsiriporn et al., 2001). Free radicals constitute irreversible lipid peroxidation and the most important product of peroxidation is malonaldehyde (MDA).

For the continuation of life it is important to maintain a stable cellular environment. The body develops defence mechanisms to prevent the damage caused by the formation of reactive oxygen species. The substances which react immediately with radicals and prevent the development of the autooxidation/peroxidation, are called antioxidants (Soto-Salanova et al., 1993; McKee \& Harrison, 1995; Ruiz et al., 2001). By decreasing intracellular disorders and diminishing the effects of stressors, the functions of these compounds include maintaining intracellular stability. Antioxidant defence is carried out in five different stages: the prevention of radical metabolite production, elimination of radical production, the repair of cell damage, inhibiting the chain reactions producing secondary radicals and increasing the endogen antioxidant capacity. Antioxidants can originate from endogenous and exogenous sources and include superoxide dismutase (SOD, E.C. 1.16.1.1), glutathione (GSH), glutathione peroxidase (GSH-Px, E.C. 1.11.1.9) and vitamin C (Aydemir et al., 2000; Puthpongsiriporn et al., 2001; Ruiz et al., 2001; Sahin et al., 2002).

Since chickens can synthesize ascorbic acid (vitamin C), it is not typically added to poultry diets 
(Satterlee et al., 1989), but the metabolic need for ascorbic acid is likely to be exceeded during pathological situations and stress. Therefore, vitamin $\mathrm{C}$ is added to poultry diets (McKee \& Harrison 1995; Puthpongsiriporn et al., 2001; Sahin et al., 2002). Stress has generally been associated with a decline in production performance. The suppression of adrenocortical steroidogenesis by vitamin $\mathrm{C}$ may constitute the primary reason why this vitamin can ameliorate the negative effects of stress (Pardue, 1987; Satterlee et al., 1989).

Although the effects of stress and vitamin $\mathrm{C}$ on some antioxidants have been investigated (Satterlee et al., 1989; McKee \& Harrison, 1995; Puthpongsiriporn et al., 2001; Sahin et al., 2002) information is limited. Therefore, it would be useful to establish the effects of vitamin $\mathrm{C}$ on some antioxidants in chickens stressed by ACTH.

\section{Materials and Methods}

In this study, 60 White Leghorn chickens (20 weeks old) were divided into two groups, a control and a vitamin $\mathrm{C}$ treated group. Blood samples were taken from both groups before application. An isotonic sodium chloride solution was administrated intramuscularly to the control group at a dose of $2.5 \mathrm{~mL}$ per chicken per day for a period of five days. Vitamin C (Redoxon Amp, Roché) was administrated intramuscularly to the experimental group at the same dose (containing $250 \mathrm{mg}$ vitamin $\mathrm{C} / 2.5 \mathrm{~mL}$ ) and period of time (Emre et al., 1994). Food and water were supplied ad libitum to both groups during the experiment. On the fifth day of the experiment each chicken in both groups received 50 I.U. ACTH (Synackten Depot, Ciba) intramuscularly (Emre et al., 1994; Trout \& Mashaly, 1994). Three hours after ACTH application, blood samples were taken to determine the concentrations of MDA and GSH, and activities of SOD and GSH-Px.

Whole blood MDA concentration as indicator of lipid peroxidation was measured, using the method based on thiobarbituric acid (TBA) reactivity, described by Jain et al. (1989). Erythrocyte SOD and GSH-Px activities were estimated in haemolysates, using commercially analytical kits (Randox Laboratory, Ireland). Whole blood GSH concentration was determined, using the method described by Beutler et al. (1963).

Because the initial values of both groups were similar, they were averaged as one initial value. Statistical analysis was done by using Covariance with the covariate the initial measurements. After application, measurements were then compared directly (Steel \& Torrie, 1980, SAS, 1985).

\section{Results and Discussion}

Under normal conditions, cells are in a steady state, which is maintained by regulatory processes and different reactive oxygen species. Free radicals such as peroxides, singlet oxygen (oxygen free radicals), superoxide, hydroxyl and peroxyl radicals are produced continuously in cells, and could lead to biological damage in cells. Against these free radical attacks, cells have developed different antioxidant systems such as the glutathion redox cycle, superoxide dismutases, catalase, glutathione peroxidases, $\alpha$-tocopherol and ascorbate (Soto-Salanova et al., 1993; Aydemir et al., 2000; Naziroğlu et al., 2000; Ruiz et al., 2001).

The concentrations of MDA and GSH, and activities of SOD and GSH-Px are presented in Table 1. Lipid peroxidation is a complex process in which the oxidation of polyunsaturated fatty acids of membrane lipids leads to membrane damage and cell death. At the onset of the present study the mean MDA concentration, which is an important sign of lipid peroxidation, was found to be $1.52 \mathrm{nmol} / \mathrm{mL}$ in both groups. After the ACTH application it was $4.08 \mathrm{nmol} / \mathrm{mL}(\mathrm{P}<0.001)$ in the control group and 1.56 $\mathrm{nmol} / \mathrm{mL}$ in the vitamin $\mathrm{C}$ treated group. This finding supported reports in the literature (Aydemir et al., 2000) that vitamin $C$ is a strong reducer of MDA concentration. Vitamin $C$ can protect the cell membrane and cytosolic component of cells against the damage of oxidants. It can produce its antioxidative effect by removing singlet oxygen hydroxyl, hydroperoxyl, superoxide, lipid peroxyl and lipid alcoksil radicals. It has been suggested that lipid peroxides produced by the oxidation of lipid molecules become soluble in water due to the antioxidative effect of vitamin C (Nikki, 1991). In addition, vitamin C prompts the synthesis of vitamin $\mathrm{E}$ from the tocopherol radicals, which do not have antioxidative activities (Levine, 1997), and vitamin $\mathrm{E}$ forms the first line of defence against oxidative stress and peroxidation of polyunsaturated fatty acids present in cellular membrane phospholipids.

Super oxide dismutase is an antioxidant enzyme and plays an important role in protecting cells against damage caused by reactive oxygen species. Super oxide dismutase protects the organism against the toxic effects of superoxide radicals by catalysing their desmutation to molecular oxygen and hydrogen peroxide $\left(\mathrm{H}_{2} \mathrm{O}_{2}\right)$ (Forman \& Fridovich, 1973). In this study; while the SOD activity after the production of experimental stress by injection was $102.82 \mathrm{u} / \mathrm{mL}$ in the control group, it was calculated to be 387.02 
$\mathrm{u} / \mathrm{mL}$ in the group injected with vitamin C. From the result of the current study, it seems that vitamin $\mathrm{C}$ utilizes its antioxidant properties by increasing SOD activity to nearly three times its normal level in order to protect cells against negative effects of stress produced by ACTH. Vitamin C protects the cell from the detrimental effects of peroxidation. This finding is in agreement with previous reports (Afanasev et al., 1986; Aydemir et al., 2000). The increased activity of SOD in the experimental group after treatment with vitamin $\mathrm{C}$ could be linked to $\mathrm{H}_{2} \mathrm{O}_{2}$ accumulation and a depletion of intracellular $\mathrm{GSH}$.

Table 1 The effect of vitamin $\mathrm{C}$ treatment on the concentrations of malonaldehyde (MDA) and glutathione (GSH), and activities of superoxide dismutase (SOD) and glutathione peroxidase (GSH-Px) before and after adrenocorticotropin (ACTH) application to chickens

\begin{tabular}{lccc}
\hline & & $\begin{array}{c}\text { Control group (2.5 mL } \\
\text { isotonic NaCl })\end{array}$ & $\begin{array}{c}\text { Vitamin C treated group } \\
(250 \mathrm{mg} \text { vit. C in 2.5 mL) }\end{array}$ \\
\cline { 2 - 4 } Parameters & $\begin{array}{c}\text { Mean initial values } \\
\text { in both groups }\end{array}$ & $\begin{array}{c}\text { After ACTH } \\
\text { application }\end{array}$ & $\begin{array}{c}\text { After ACTH } \\
\text { application }\end{array}$ \\
\cline { 2 - 4 } MDA $(\mathrm{nmol} / \mathrm{mL})$ & $1.52 \pm 0.4^{\mathrm{a}}$ & $4.08 \pm 0.9^{\mathrm{b}}$ & $1.56 \pm 0.4^{\mathrm{a}}$ \\
SOD $(\mathrm{u} / \mathrm{mL})$ & $95.41 \pm 9.7^{\mathrm{a}}$ & $102.82 \pm 9.8^{\mathrm{a}}$ & $387.02 \pm 30.4^{\mathrm{b}}$ \\
GSH $(\mathrm{mg} / 100 \mathrm{~mL})$ & $75.56 \pm 7.2$ & $73.94 \pm 8.4$ & $74.44 \pm 7.6$ \\
GSH-Px $(\mathrm{u} / \mathrm{mL})$ & $34.50 \pm 1.85$ & $41.37 \pm 4.09$ & $38.81 \pm 5.05$ \\
\hline
\end{tabular}

${ }^{\mathrm{a}, \mathrm{b}}$ Means in the same row with different superscripts differ significantly $(\mathrm{P}<0.001)$

In order to avoid damage of reactive agents, tissues require sufficient concentrations of biological antioxidants such as GSH and vitamin C, and this plays critical roles in the neutralization oxidants (Avanzo et al., 2001; Hoffman, 2002). In this study, it was determined that GSH concentration in control and vitamin $\mathrm{C}$ treated groups decreases slightly after the ACTH application compared with the pre-experiment phase. Glutathione in tissue can be converted into GSSG by GSH-Px during stress produced by ACTH. Vitamin C can be facilitated non-enzymatically by GSH in tissues. This decrease in GSH may not only be a result of vitamin $\mathrm{C}$ treatment, but also because of increased tissue susceptibility to the deleterious effects of free radicals, as GSH itself is a powerful antioxidant and can be used in stress. Moreover, vitamin $\mathrm{C}$ can react directly with aqueous free radicals such as the hydroxyl and peroxyl radicals by donating one electron and quenching their reactivity.

Glutathione peroxidase together with SOD and catalase protects cells against damage caused by free radicals and hydro- or lipoperoxides (Macpherson, 1994). In this study, the GSH-Px activity increased in the control and vitamin $\mathrm{C}$ treated groups after ACTH application, but the increase was not statistically significant. Some reports indicated that the rise in GSH-Px activity may be a response to the need for further enzymatic capacity to deal with the production of $\mathrm{H}_{2} \mathrm{O}_{2}$ possibly associated with increased SOD activity and plasma vitamin C level (Aydemir et al., 2000; Öztürk-Ürek et al., 2001).

Results of the present study suggested that vitamin $\mathrm{C}$ exhibits protection against negative effects of stress induced by ACTH.

\section{References}

Afanasev, I.B., Grabovetski, V.V., Kuprianova, N.S. \& Guner, V.I., 1986. In: Superoxide and Superoxide Dismutase in Chemistry, Biology and Medicine. Ed. Rotilio, R., Elsevier Science B.V. Biomedical Division.

Avanzo, J.L., Mendonca, C.X., Pugine, S.M. \& Cesar, M.C., 2001. Effect of vitamin E and selenium on resistance to oxidative stress in chicken superficial pectoralis muscle. Comp. Biochem. Phys. C. $129,163-173$. 
Aydemir, T., Ozturk, R., Bozkaya, L.A. \& Tarhan, L., 2000. Effects of antioxidant vitamins A, C, E and trace elements $\mathrm{Cu}, \mathrm{Se}$ on CuZn SOD, GSH-Px, CAT and LPO levels in chicken erythrocytes. Cell Biochem Funct. 18, 109-115.

Beutler, E., Duron, O. \& Kelly, M., 1963. Improved method for the determination of blood glutathione. J. Lab. Clin. Med. 61, 882-885.

Emre, B., Sulu, N., Hatipoglu, F. \& Çınar, A., 1994. C vitamini uygulanan ve uygulanmayan tavuklarda ACTH nın glukoz ve insülin düzeylerine etkisi. A.Ü.Vet. Fak.Derg. 41, 10-47.

Forman, H.J. \& Fridovich, I., 1973. On the stability of bovine superoxide dismutase: the effects of metals. J. Biol. Chem. 248, 2645-2649.

Gray, H.G., Paradis, T.J. \& Chang, P.W., 1989. Research note: Physiological effects of adrenocorticotropic hormone and hydrocortisone in laying hens. Poult. Sci. 68, 1710-1713.

Hoffman, D.J., 2002. Role of selenium toxicity and oxidative stress in aquatic birds. Aquat. Toxicol. 57, 1126.

Husveth, F., Manilla, H.A., Gaal, T., Vajdovich, P., Balogh, N., Wagner, L., Loth, I. \& Nemeth, K., 2000. Effects of saturated and unsaturated fats with vitamin E supplementation on the antioxidant status of broiler chicken tissues. Acta Vet. Hung. 48, K. 69-79.

Jain, S., McVie, R., Duett, J. \& Herbest, J., 1989. Erythrocyte membrane lipid peroxidation and glycolyated hemoglobin in diabetes. Diabetes 38, 1539-1543.

Levine, M., 1997. New concepts in biology and biochemistry of ascorbic acid. New Engl. J. Med. 314, 892901.

Macpherson, A., 1994. Selenium, vitamin E and biological oxidation. In: Recent Advances in Animal Nutrition. Eds. Cole, D.J \& Garnsworthy, P.J., Butterworth and Heinemann's, Oxford. pp. 3-30.

McKee, J.S. \& Harrison, P.C., 1995. Effects of supplemental ascorbic acid on the performance of broiler chickens exposed to multiple concurrent stressors. Poult. Sci. 74, $1772-1785$.

Naziroglu, M., Sahin, K., Simsek, H., Aydilek, N. \& Ertas, O.N., 2000. The effects of food withdrawal and darkening on lipid peroxidation of laying hens in high ambient temperatures. Dtsch Tierarztl Wochenschr. 107, 199-202.

Niki, E., 1991. Vitamin C as an antioxidant. Wld Rev. Nutr. Diet. 64, 3-30.

Öztürk-Ürek, R., Bozkaya, L.A. \& Tarhan, L., 2001. The effects of some antioxidants vitamin and trace elements supplemented diets on activities of SOD, CAT, GSH-Px and LPO levels in chicken tissues. Cell Biochem. Funct. 19, 125-132.

Pardue, S.L., 1987. Recent findings on vitamin C supplementation in poultry. In: The role of vitamins on animal performance and immune response. Roché Tech. Symp., Daytona Beach, Florida. pp.18-33.

Puthpongsiriporn, U., Scheideler, S.E., Sell, J.L. \& Beck, M.M., 2001. Effects of vitamin E and C supplementation on performance, in vitro lymphocyte proliferation, and antioxidant status of laying hens during heat stress. Poult. Sci. 80, 1190-1200.

Puvadolpirod, S. \& Thaxton, J.P., 2000. Model of physiological stress in chickens. 2. Dosimetry of adrenocorticotropin. Poult Sci. 79, 370-376.

Ruiz, J.A., Guerrero, L., Arnau, J., Guardia, M.D. \& Esteve-Garcia, E., 2001. Descriptive sensory analysis of meat from broilers fed diets containing vitamin $\mathrm{E}$ or beta-carotene as antioxidants and different supplemental fats. Poult. Sci. 80, 976-82.

Sahin, K., Sahin, N. \& Yaralioglu, S., 2002. Effects of vitamin C and vitamin E on lipid peroxidation, blood serum metabolites, and mineral concentrations of laying hens reared at high ambient temperature. Biol. Trace Elem. Res. 85, 35-45.

SAS, 1985. Statistical Analysis System user's guide. (5th ed.). SAS Institute, Inc., Cary, North Carolina, USA.

Satterlee, D.G., Aguilera, I., Munn, B.J. \& Krautmann, B.A., 1989. Vitamin C amelioration of the adrenal stress response in broiler chickens being prepared for slaughter. Comp. Biochem. Phys. 94A(4), 569-574.

Siegel, H.S., 1971. Adrenals, stress, and the environment. Wld Poult. Sci. J. 27, 327-349.

Soto-Salanova, M.F., Sell, J.L., Mallarino, E.G., Piquer, F.J., Barker, D.L., Palo, P.E. \& Ewan, R.C., 1993. Research note: vitamin E status of turkey poults as influenced by different dietary vitamin E sources, a bile salt, and an antioxidant. Poult. Sci. 72, 1184-1188.

Steel, R.G. \& Torrie, J.H., 1980. Principle and Procedures of Statistics (2nd ed.). McDonald book Co., Inc., New York. 
(C) South African Society for Animal Science

Trout, J. M. \& Mashaly, M. M., 1994. The effects of adrenocorticotropic hormone and heat stress on the distribution of lymphocyte populations in immature male chickens. Poult. Sci. 73, 1694-1698.

Whittow, G.C., 2000. Sturkie's avian physiology. $5^{\text {th }}$ ed. Academic Pres, New York. 